\title{
INTERSECTING ASYMMETRIES: \\ THE INTERNATIONALIZATION OF TURKEY IN THE 1920S AND THE LIMITS OF THE POSTCOLONIAL APPROACH
}

\section{CAROLIN LIEBISCH-GÜMÜŞ}

KIEL UNIVERSITY

\begin{abstract}
Previous studies of Turkey's relations with the League of Nations suggest that in the 1920s, the relationship was marked by Turkey's exclusion from the League and disputes over territories and sovereignty. Only at the end of the decade did Turkey begin to join the international community, culminating in its becoming a member of the League in 1932. This article proposes a fresh reading of Turkey's internationalization (i.e., its participation in international organizations) in the 1920s. Not only do we begin to see Turkish membership in a considerable number of smaller international organizations, but the government also developed ties with the League Secretariat and the International Labour Office, even though it formally remained a non-member of the League. These more subtle forms of cooperation, this article argues, were part of a balanced strategy of internationalization that reflected the (semi)colonial underpinnings of many international organizations and the Ottoman experience with them. This internationalization strategy was grounded in the Kemalists' ideological conceptualization of the global order as profoundly shaped by European hegemony. In so arguing, this article adopts a postcolonial perspective. However, it also points out the limits of such a perspective, stressing that power asymmetries on the international level were connected with internal asymmetries within Turkey itself.

Keywords: Turkey; international organizations; League of Nations; International Labour Organization; nation building; post-colonialism
\end{abstract}

DOI: $10.14712 / 23363231.2019 .15$

Carolin Liebisch-Gümüş, M.A., is a lecturer and postdoctoral researcher at Kiel University. Address correspondence to History Department, Kiel University, Olshausenstraße 40, D-24098 Kiel, Germany. E-mail: liebisch@histosem.uni-kiel.de. 


\section{Introduction}

A famous interview that appeared in September 1923 in the U.S. weekly magazine, the Saturday Evening Post, was one of the few occasions where the leader of the "new Turkey," Mustafa Kemal (Atatürk), publicly shared his opinions about the League of Nations. Asked whether Turkey was going to join the organization, he cautiously replied, "conditionally." He stressed a need for improvement of the organization: "The League's error lies in that it sets up certain nations to rule, and other nations to be ruled. The Wilsonian idea of self-determination seems to be strangely lost."

Mustafa Kemal's opinion reflected not only the general feeling of the Turkish government and the wider elite in Turkey, it also fit into a global pattern. Elites from various colonized and semi-colonized countries in Africa and Asia had experienced a roller coaster of expectations regarding the post-World War I international order. Based mainly upon the wartime speeches of Woodrow Wilson, they welcomed the prospect of a global community consisting of independent and equal nation states. Such a community, they thought, would reduce the power asymmetries that had characterized the international order to that date. Their hopes for a new era of international organization ${ }^{2}$ were soon shattered. They realized that the League and its system of mandates would perpetuate the great powers' imperialistic designs. The reactions of Turkey's elite to this disappointment are the central theme of this article.

Historical scholarship has paid considerable attention to the enthusiasm for Wilsonian ideas that emerged during World War I, and the repercussions and frustrations worldwide. Erez Manela's pivotal study of Wilsonianism in Egypt, India, China, and Korea showed how failed hopes for national self-determination incited local resistance to external influence and manifestations of anti-colonial feeling. ${ }^{3}$ Other books touch upon the disappointment and engagement of elites in existing and former colonies with the League of Nations itself. ${ }^{4}$ The gap that still exists in the literature about such feelings towards the League in Turkey is worth filling.

1 Isaac F. Marcosson, “Kemal Pasha," Saturday Evening Post, September 20, 1923, 145.

2 The use of the term "international organization" in the singular form emphasizes the role of internationalism within the international order. In this article, it specifically refers to Geneva-based "liberal" internationalism.

3 Erez Manela, The Wilsonian Moment. Self-Determination and the International Origins of Anticolonial Nationalism (Oxford: Oxford University Press, 2007), 221, 224.

4 E.g. Thomas W. Burkman, Japan and the League of Nations. Empire and World Order 1914-1938 (Honolulu: University of Hawai'i Press, 2008); Thomas Fischer, Die Souveränität der Schwachen. Lateinamerika und der Völkerbund 1920-1936 (Stuttgart: Franz Steiner, 2012). See also works that 
Works that adopt a postcolonial perspective on interwar internationalism have proven valuable for our general understanding of international organizations. They identify the colonial structures and the ideas that shaped international organizations in the nineteenth century. They document those organizations' enduring legacies and their evolution into the League of Nations and the United Nations. ${ }^{5}$ Asking how "non-Western" actors made sense of, dealt with, and even challenged imperialistic internationalism helps us to broaden the narrative beyond a simple dichotomy between inclusion and exclusion. That is the goal of this article. It sheds light on the attitude of Turkish officials towards internationalization ${ }^{6}$ in the 1920 s and particularly towards the League of Nations.

The 1920s were the first decade for both the League and postwar Turkish nation-building. It was the seminal period in the internationalization of the "new Turkey." Drawing mainly upon the archives of the League of Nations, as well as diplomatic documents and published treatises, this article reveals how Turkish actors tried to reshape the terms of internationalization to their advantage. It investigates their strategies for challenging the colonial asymmetries that were inherent in the League and preserving Turkey's sovereignty as it sought to integrate itself into the international community.

It is true that Turkey and the Ottoman Empire - apart from certain Mediterranean islands and its former provinces in North Africa and Arabia - never fell under direct European colonial rule. Nonetheless, Turkey was the target of imperialistic infiltration and colonial scheming from the nineteenth century up into the post-1918 years. International bodies played a major role in those colonial schemes. Consequently, the reaction to those colonial schemes, as

discuss petitions to the League Mandate Commission as a means for questioning colonial rule: Caroline Authaler, Deutsche Plantagen in Britisch-Kamerun. Internationale Normen und lokale Realitäten 1925 bis 1940 (Köln: Böhlau, 2018); Susan Pedersen, The Guardians. The League of Nations and the Crisis of Empire (Oxford: Oxford University Press, 2015).

5 Madeleine Herren, "Internationale Zwangsverwaltungen. Perspektiven einer postkolonialen Geschichte internationaler Organisationen," in Zwangsadministrationen. Legitimierte Fremdverwaltung im historischen Vergleich, 17.-21. Jahrhundert, ed. Fabian Frommelt (Berlin: Duncker \& Humblot, 2014), 143-162; Mark Mazower, No Enchanted Palace. The End of Empire and the Ideological Origins of the United Nations (Princeton: Princeton University Press, 2009); Pedersen, The Guardians.

6 Like Madeleine Herren, I understand "internationalization" as the implementation of an internationalization strategy, i.e. a foreign policy agenda promoting participation in multilateral, cross-border schemes of cooperation and the integration of state structures into international organizations. Cf. Madeleine Herren, Hintertüren zur Macht. Internationalismus und Modernisierungsorientierte Außenpolitik in Belgien, der Schweiz und den USA 1865-1914 (München: Oldenbourg, 2000), 14. 
this article demonstrates, had much to do with the way Turks approached the League and other international organizations in the 1920s. The article takes its inspiration from postcolonial perspectives on the history of international organizations, but also discusses the limits of such a perspective in this particular case. It advances the argument that asymmetries at the international level were linked to asymmetries within Turkey that were influenced by nationalism - hence the title "intersecting asymmetries" is appropriate. ${ }^{7}$

So far, research into Turkey's foreign relations in the 1920s has not strayed far from the paths of diplomatic history. Surveys focus on bilateral and multilateral relations, but pay little attention to international organizations. ${ }^{8}$ Most studies that do include Turkey's relations with international organizations focus exclusively on the League and its constituent bodies, the Council, the Assembly, and the Court. ${ }^{9}$ The League Secretariat, on the other hand, with its many specialized commissions, remains largely undiscussed. So does the plethora of other organizations with which Turkey was involved. ${ }^{10}$

As a result, one gains the impression from the literature that for Turkey, internationalization really began only a few years prior to 1932, the year Turkey became a member of the League. The 1920s, on the other hand, are depicted as an almost non-internationalist period, when a phase of initial distrust of the League resulting from postwar peace-making evolved into a full retreat from internationalism after the League's decision to hand Mosul over to Iraq in 1926.

\footnotetext{
7 Similarly, Jane Cowan speaks of a "dynamic of mirrored asymmetry" in her paper on the League of Nations' minority protection regime. Cowan discusses contradictions between national claims for international justice and minority rights. See Jane Cowan, "Justice and the League of Nations Minority Regime," in Mirrors of Justice. Law and power in the post-Cold War era, ed. Kamari Maxine Clarke and Mark Goodale (Cambridge: Cambridge University Press, 2010), 270-290.

${ }^{8}$ Mehmet Gönlüböl and Cem Sar, Atatürk ve Türkiye’nin Dış Politikası (1919-1938) (Ankara: AYK, 2013); William Hale, Turkish Foreign Policy 1774-2000 (London: Frank Cass, 2000).

9 Özden Zeynep Alantar, “Türk Dış Politikasında Milletler Cemiyeti Dönemi," in Türk Dış Politikasının Analizi, ed. Faruk Sönmezoğlu (Istanbul: Der Yayınevi, 1994), 99-129; Dilek Barlas, "Milletler Cemiyeti’nde Türkiye: İyimserlik ve Kuşku Arasında," Uluslararası İliş̧kiler 14, No. 55 (2017): 93-111, doi: 10.33458/uidergisi.513523; Yücel Güçlü, “Turkey’s Entrance into the League of Nations," Middle Eastern Studies 39, No. 1 (January 2003): 186-206, doi: 10.1080/00263200412331301637. Without mentioning, Güçlü frequently cites an earlier study: Turkey and the United Nations, prepared under the auspices of the Institute of International Relations of the Faculty of Political Sciences at the University of Ankara for the Carnegie Endowment for International Peace (New York: Manhattan Publishing Company, 1961).

${ }^{10}$ On the historiographical turn towards international bureaucracies see, Madeleine Herren, "Introduction. Towards a Global History of International Organization," in Networking the International System. Global Histories of International Organizations, ed. Madeleine Herren (Heidelberg: Springer, 2014), 1-14.
} 
Later, a phase of rapprochement emerged at the close of the decade, leading to Turkey's membership in the League. ${ }^{11}$

As regards the reasons for Turkey's declining to join the League until 1932, scholars usually cite the League's response to the Mosul Question. The decision as to whether the oil-rich Ottoman province should belong to British-controlled Iraq or to Turkey was made by a League fact-finding commission and the League Council. They decided in favor of the British - a decision that enraged the Turks. Turkey's sensitive relations with the leadership of the Soviet Union, which opposed the capitalist global power the League supposedly embodied, is another frequently invoked reason for its hesitancy. ${ }^{12}$ To explain the later rapprochement with the League, most historians point to a warming of relations with the European powers, but also to the rising threat of Italian expansionism, which goaded the Turkish government to seek collective security. ${ }^{13}$ Overall, Turkish foreign relations during the period before 1932 were believed to be determined by its national preferences, bilateral relations, geopolitical disputes, and security interests. As important as these factors are, in my opinion, they still do not suffice to explain fully not only Turkey's bustling internationalist activities in the 1920s, but also the complex relationship between the Kemalist elites and the League.

It is beyond the scope of this article to offer a comprehensive survey of internationalist ventures undertaken by Turkish actors or even just by the Turkish government. Nor can it claim to deliver an in-depth study of all of Turkey's motives for embracing internationalism. The most it can hope to do is to sketch out the contours of an alternative framework for analyzing Turkey's internationalization in the 1920s. The first chapter situates the "new Turkey's" internationalization in the broader history of imperialistic internationalism since the nineteenth century. As the second chapter goes on to show, the asymmetric international integration of the prewar Ottoman Empire had a profound impact on the Kemalists' incentives and strategies for internationalization after World War I. I argue that their goal was "symmetrical internationalization." Understanding that helps us rethink the question of Turkey's League membership in

11 Şayan Ulusan's (largely descriptive) article contrasts this impression mentioning Turkish involvement in various early activities of the League of Nations. Şayan Ulusan, "Türkiye'nin Milletler Cemiyeti’ne Girişi. Öncesi ve Sonrası,” Çağdaş Türkiye Tarihi Araştırmaları Dergisi 7, No. 16-17 (2008): 237-258.

12 Barlas, "Milletler Cemiyeti’nde Türkiye," 98; Güçlü, “Turkey’s Entrance," 190, 198; Turkey and the United Nations, 19.

13 Barlas, “Milletler Cemiyeti’nde Türkiye,” 99; Hale, Turkish Foreign Policy, 72. 
the 1920s, which is the topic of the third chapter focusing on Turkey's dealings with the League Secretariat and the ILO Bureau.

In chapter 4, the ideological framework of Turkish nationalism comes to the fore. Focusing on the highly influential theories of Ziya Gökalp, I highlight the ideological premises behind the Kemalists' attitude to internationalism. ${ }^{14}$ Revealing how nationalism and internationalism converged in Kemalist thinking, I suggest that anti-imperialist nationalism should be understood as an ambiguous internationalization strategy, which manifested internal power hierarchies. Taking this discussion further, I close with some remarks on potential problems raised by a postcolonial reading of Turkey's relationships with international organizations.

\section{Imperialistic Legacies and International Asymmetries}

The new government that was formed in Ankara in April 1920 by the National Movement took an ambivalent stance towards the League of Nations. The League had endorsed the much-detested Treaty of Sèvres, which was the nationalists' prime obstacle in their fight to gain independence and control of the Turkish state. Charged with implementing several of the Treaty's stipulations, the League had supported the conversion of former Ottoman territories into British and French mandates. ${ }^{15}$ Even worse, it had endorsed the division of Anatolia - the nationalists' homeland - into spheres of European and Greek influence and an independent Armenian state. Equally alarming to the nationalists was the general assumption that under Sèvres, the League would continue the western imperialism that the Ottomans had experienced in their progress toward internationalization. In the past, the Ottoman Empire had participated in several of the international organizations that preceded the foundation of the League after World War I. However, it had never managed to negotiate a level playing field in those organizations. On the contrary, its international commitments had paved the way for increased European encroachment on Ottoman sovereignty.

${ }^{14}$ Since the 1990s, cultural histories of international relations have stressed the role of culture and ideas in the formation of politics. Questions of political power are answered by reference to discourses and modes of perception. For a recent example of such a discussion see Patrick Finney, "Anglo-American International History after the Cultural Turn," in Internationale Geschichte in Theorie und Praxis / International History in Theory and Practice, ed. Barbara Haider-Wilson, William D. Godsey, and Wolfgang Mueller (Vienna: ÖAW, 2017), 231-252.

15 On mandates in general, see Pedersen, The Guardians. 
The nineteenth century in the Ottoman Empire was not only an era of reform and modernization, but also of internationalization. Unlike most other Muslim countries at that time, the Ottomans entered onto the international scene as an independent state. The government maintained permanent diplomatic missions in the capitals of Europe, ${ }^{16}$ and the Congress of Paris (1856) confirmed its membership in the European Concert of Powers. ${ }^{17}$ Besides these diplomatic achievements, the Ottoman government also participated in many of the specialized international organizations that originated during the latter half of the century. The Sublime Porte joined public international unions such as the International Telegraph Union (1865) and the General Postal Union (1874). ${ }^{18}$ The establishment of the Red Crescent in 1868 signaled Turkey's early alignment with the Red Cross Movement. ${ }^{19}$ Ottoman representatives also attended all of the International Sanitary Conferences convened between 1851 and 1911, which aimed to curb cross-border epidemics. The Turks even hosted the Sanitary Conference of 1866 in Istanbul. ${ }^{20} \mathrm{By}$ 1914, the Empire was a member of more international organizations than China or Japan, which had previously made a similar opening to the West. ${ }^{21}$ Taken together, this list of examples underlines the early and comprehensive inclusion of Ottoman representatives in the new world of international organizations.

However, Maurus Reinkowski’s remark about Ottoman-European-relations - that the Ottoman Empire occupied a contradictory position between internationally recognized power and "semi-colonial status" 22 - is equally true

${ }^{16}$ By the mid-1830s, in London, Paris, Vienna, and Berlin. See Ömer Kürkçüoğlu, “The Adaption and Use of Permanent Diplomacy," in Ottoman Diplomacy. Conventional or Unconventional? ed. A. Nuri Yurdusev (Basingstoke: Palgrave Macmillan, 2004), 131-150.

17 Fikret Adanır, “Turkey's Entry into the Concert of Europe," European Review 13, No. 3 (2005): 395-417, doi: 10.1017/S1062798705000530.

18 Documents diplomatiques de la conférence télégraphique internationale de Paris (Paris, 1865), 7; Treaty Concerning the Formation of a General Postal Union, signed at Berne, October 9, 1874, Washington 1875, 16.

19 Mesut Çapa, “Kızılay,” TDV İslam Ansiklopedisi, Vol. 25 (Ankara: Türkiye Diyanet Vakfı, 2002), 544-546.

${ }^{20}$ Valeska Huber, "The Unification of the Globe by Disease? The International Sanitary Conferences on Cholera 1851-1894," The Historical Journal 49, No. 2 (2006): 453-476, doi: 10.1017/ S0018246X06005280; Nermin Ersoy, Yüksel Güngör, and Aslıhan Akpınar, "International Sanitary Conferences from the Ottoman Perspective 1851-1938," Hygiea Internationalis. An Interdisciplinary Journal for the History of Public Health 10, No. 1 (2011): 53-79, doi: 10.3384/hygiea.1403-8668.1110153.

21 Turan Kayanoğlu, Legal Imperialism. Sovereignty and Extraterritoriality in Japan, the Ottoman Empire and China (Cambridge: Cambridge University Press, 2010), 109.

22 Maurus Reinkowski, "Das Osmanische Reich. Ein antikoloniales Imperium?” Zeithistorische Forschungen/Studies in Contemporary History 3, No. 1 (2006): 34-54, here 41; See also Ergil Doğu, "Development of Turkish Semi-Colonialism," Islamic Studies 18 (1979): 183-229. 
about the Ottomans' internationalization. While recognizing that the Ottoman Empire was becoming integrated into international organizations, one must add that this integration was profoundly asymmetric and was shaped by European imperialism. ${ }^{23}$ Nowhere is this more evident than in the case of the Ottoman Public Debt Administration (OPDA). Founded in Istanbul in 1881 after the financial collapse of the Ottoman state, this bureaucratic apparatus served the ends of Turkey's European creditors, granting them considerable control over Ottoman state finances. The OPDA was not founded on an international agreement or staffed by foreigners with diplomatic status. It was formally an Ottoman state agency, not an international governmental organization. However, its board of directors was composed mostly of foreign nationals who represented the European creditors. They had the authority to hire the agency's staff (nearly two hundred Europeans worked in the higher ranks of the agency), who collected the Ottoman state's taxes and redistributed the revenue to its bondholders. ${ }^{24}$ The agency was in fact an "international body" 25 that undermined the Ottoman Empire's sovereignty.

The international sanitary cooperation mentioned above was another domain where Ottoman sovereignty was yielded up in the course of its internationalization. At the Sanitary Conferences, British and French delegates branded the Middle East as an epidemiological threat to Europe and therefore insisted on extending their control in the region. ${ }^{26}$ Under the same pretext and with the permission of the reform-minded Sultans, a Supreme Council of Health was established in Istanbul. By the year 1847, the majority of its staff were foreign experts from twelve European countries and the United States. ${ }^{27}$

23 On the imperialistic tendencies of international organizations in the nineteenth century, see Madeleine Herren, "International Organizations, 1865-1945," in The Oxford Handbook of International Organizations, ed. Jacob Katz Cogan, Ian Hurd, and Ian Johnstone (Oxford: Oxford University Press, 2016), 91-112, here 94-95.

${ }^{24}$ Murat Birdal, The Political Economy of Ottoman Public Debt. Insolvency and European Financial Control in the Late Nineteenth Century (London: I. B. Tauris, 2010), 103-105; Şevket Pamuk, Uneven Centuries. Economic Development of Turkey since 1820 (Princeton: Princeton University Press, 2018), 109-110.

25 Herren, "International Organizations," 95. Herren adopts a broad definition of international organizations as networks that shape interactions between state agents and non-state actors, beyond the borders of the nation state.

${ }^{26}$ Huber, "The Unification of the Globe," 462. Also, Francisco Javier Martínez, "International or French? The Early International Sanitary Conferences and France's Struggle for Hegemony in the Mid-Nineteenth Century Mediterranean," French History 30, No. 1 (2016): 77-98, here 84-85, 98, doi: $10.1093 / \mathrm{fh} / \mathrm{crv} 035$.

27 Gülden Sarıyıldız, "Karantina Meclisi’nin Kuruluşu ve Faaliyetleri," TTK Belleten 58, No. 222 (1994): 329-376. 
The Council exerted influence over internal Ottoman policies on behalf of its mainly European beneficiaries. Ersoy et al. speak of it as an "extension of Capitulations through the health care area." 28 The Capitulations were a series of contracts between the Ottomans and European (later also American) governments that granted special rights to nationals of the contracting states living in the Ottoman Empire as well as to their Ottoman intermediaries. Comparing the Council of Health to the Capitulations, the authors stress that both institutions promoted foreign influence and commercial interests within an international framework.

The Capitulations were yet another example that illustrated how embracing internationalism was fraught with imperialistic pitfalls. Although the Capitulations themselves did not add up to an international organization as such, they did constitute an important element of international law that affected the Empire. Granting legal immunities and economic privileges, they were, in the words of Turan Kayanoğlu, a form of "legal imperialism." ${ }^{29}$ The Capitulations as well as the other examples of asymmetric internationalism cited above found a powerful justification in nineteenth century international law. The "standard of civilization," was a concept invoked by European politicians and legal experts alike. It legitimized foreign intervention into non-Western societies that allegedly lacked civilization in the European sense and therefore did not merit respect as truly sovereign entities. ${ }^{30}$

It is from this background of the Ottoman experience with prewar imperialistic internationalism that we gain deeper understanding of Turkey's approach to internationalization in the 1920s. The League of Nations was a fundamentally new kind of international organization, but it was also connected with many prewar structures. The League's Secretariat acted as a kind of switchboard for a whole spectrum of international cooperation already underway - political, humanitarian, and "technical." 31 The League's broad field of activity enabled the

${ }^{28}$ Ersoy et al., "Sanitary Conferences," 73. See also, Osman Şevki Uludağ, Son Kapitülasyonlardan Biri Karantina (Istanbul: Devlet Yayınları, 1938). The Supreme Council of Health functioned as the central body, with branch offices in Anatolia and the Balkans. The Council was also associated with similar institutions in Alexandria (1831), Tunis (1835), Tangier (1840) and Tehran (1868).

${ }^{29}$ Kayanoğlu, Legal Imperialism, 107.

${ }^{30}$ Gerrit W. Gong, The Standard of Civilization in International Society (Oxford: Clarendon Press, 1984). For the Ottoman case, see Rodogno, "European Legal Doctrines on Intervention and the Status of the Ottoman Empire within the "Family of Nations', Journal of the History of International Law 18, No. 1 (2016): 5-41, doi: 10.1163/15718050-12340050.

31 Susan Pedersen, "Back to the League of Nations," The American Historical Review 112, No. 4 (2007): 1091-1117, 1108, doi: 10.1086/ahr.112.4.1091. In the Secretariat's jargon, "technical or- 
victorious powers who founded the League in 1919 to consolidate their previous imperialistic undertakings in one place. The League's mechanism for international territorial administration (mandates) allowed them to strip the Ottoman Empire of its sovereignty over parts of its former territory. Following the Paris Peace Conference, the Ottoman Arab provinces fell under British and French suzerainty in the form of League mandates. The League also secured international control over the Turkish Straits. In addition, the peacemakers in Paris discussed various schemes for internationalizing Istanbul and transforming the rest of Ottoman Anatolia - minus those territories that were to pass into Greek and Armenian sovereignty - into a mandate or some other sort of semi-sovereign protectorate under the auspices of the League. ${ }^{32}$

In addition to territorial administration, the League Secretariat's technical organizations enabled more indirect ways of control. The old Supreme Council of Health, for instance, was continued according to the Sèvres Treaty under the auspices of the League and its Health Section. ${ }^{33}$ So was the European Powers' humanitarian interference in favor of non-Muslim minorities. After being a vehicle for European influence in the Ottoman Empire since the nineteenth century, foreign interventionism was embedded in the League's protection of minorities as provided for in the Treaty of Sèvres. ${ }^{34}$ At the same time, the League's efforts to support Ottoman refugees and minorities answered to a real humanitarian crisis, since the survivors of the Armenian genocide as well as Greeks and other Christians were in bitter distress after the war. ${ }^{35}$ The Turkish nationalists, however, denied the humanitarian dimension and dismissed

ganizations" meant the League's specialized sections that dealt with cross-border issues such as refugees, epidemics, opium trafficking, and trade.

32 On partition plans involving the League, see the classics: Paul C. Helmreich, From Paris to Sèvres. The Partition of the Ottoman Empire at the Peace Conference of 1919-1920 (Columbus: Ohio State University Press, 1974); Harry N. Howard, The Partition of Turkey. A Diplomatic History 19131923 (New York: University of Oklahoma Press, 1966).

33 Treaty of Sèvres, in The Treaties of Peace, 1919-1923, ed. Lawrence Martin (New York: Carnegie Endowment for International Peace, 1924), 801-802.

34 On the prewar history, see Davide Rodogno, Against Massacre. Humanitarian Interventions in the Ottoman Empire, 1815-1914. The Emergence of a European concept and International Practice (Princeton: Princeton University Press, 2012).

35 Among the growing literature on the topic, see Davide Rodogno, "Non-state actors' humanitarian operations in the aftermath of the First World War," in The Emergence of Humanitarian Intervention. Ideas and Practice from the Nineteenth Century to the Present, ed. Fabian Klose (Cambridge: Cambridge University Press, 2015), 185-207; Keith David Watenpaugh, Bread from Stones. The Middle East and the Making of Modern Humanitarianism (Oakland: University of California Press, 2015). 
international minority protection as an imperialist tool and a threat to national sovereignty. 36

The Allies also reinstated the Capitulations. Though the Capitulations involved the League only indirectly, their continuation was part of an overall strategy that was to erode Turkish sovereignty through the Treaty of Sèvres and within the League system. ${ }^{37}$ Imperialist structures outlasted World War I, and so did the discourse that supported them. The "standard of civilization" was an undertone that resonated from the Peace Conference in Paris to the League of Nations in Geneva. The Allies justified their partition plans for the Ottoman Empire by allegations of the Turks' incapacity to rule justly and their barbarousness, which they saw confirmed by past violence against minorities. ${ }^{38}$

The Turkish nationalist leaders themselves used the term "Capitulations" as an epithet denoting all international agreements and organizations that they perceived as imperialist threats to Turkey's sovereignty. At the Lausanne Conference in 1922-23, where Allied and Turkish representatives negotiated a new peace to supplant the Sèvres Treaty, the Turkish side categorically rejected all legal, sanitary, and financial "capitulations" as well as any extensive regime for protection of minority rights. In their eyes, these were issues "of a kind to impair Turkey's sovereignty and independence." 39 They were wary of perpetuating the asymmetric commitments of their Ottoman predecessors. Their insistence on national independence and sovereignty met with considerable success. The Treaty of Lausanne abolished - albeit with some compensations - the Capitulations, the Ottoman Public Debt Administration in its original form, and the Supreme Council of Health. ${ }^{40}$ As a result, the Ankara

36 Watenpaugh, Bread from Stones, 150-153. Unfortunately, the role of minority politics for the internationalization of Turkey can only be touched upon in this article, because it is so complex that I decided to dedicate a separate publication to it.

37 While the League facilitated attempts to maintain former obligations that limited Ottoman sovereignty, it must be noted that such attempts also took place outside the League, for instance in the investment sector. On protectionist policies and the question of economic sovereignty, see Feroz Ahmad, "The Political Economy of Kemalism," in Atatürk. Founder of a Modern State, ed. Ali Kazancigil and Ergun Özbudun (London: C. Hurst, 1981), 145-163, 146-147, 149-150; Pamuk, Uneven Centuries, 169-170.

38 “Allies Reject Turkey's Plea," The New York Times, June 27, 1919.

${ }^{39}$ Minutes of the Fifth Meeting, January 27, 1923, in Lausanne Conference on Near Eastern Affairs. Records of Proceedings and Draft Terms of Peace (hereafter LCR), presented to Parliament by Command of His Majesty, printed and published by His Majesty's Stationary Office, London 1923, 595-596; Hüseyin Rauf to İsmet Pasha, December 17, 1922, in Lozan Telegrafları I, ed. Bilâl N. Şimşir (Ankara: Türk Tarih Kurumu, 1990), 233.

40 The OPDA did not cease to exist, but it no longer controlled tax policies. In return for abolishment of the Capitulations, the government had to promise to rewrite its legal code within only 
government had autonomous responsibility for defining a new legal framework for residency of aliens, debt repayments, and ensuring sanitary control along its coasts and borders. These areas of responsibility, which had hitherto been door-openers for imperialist infiltration, passed from a regime of asymmetric internationalization to national control. However, as we shall see in the next chapter, to the western-oriented Kemalists the alternative to asymmetric internationalization was not isolationism, but "symmetric" (i.e. self-determined and sovereign) internationalization.

\section{From Asymmetric to Symmetric Internationalization}

In the 1920s, internationalism was booming. ${ }^{41}$ The LONSEA database, which analyzes handbooks on international organizations published by the League of Nations, registers an increase in the number of international organizations and associations from 205 to 339 between 1921 and $1929 .{ }^{42}$ At the same time, the League Secretariat itself expanded, developing specialized substructures in fields like health, social welfare, transit, and opium control. ${ }^{43}$ Turkey was part of the general trend. The graph below shows that the number of international organizations in which Turkey was a member doubled to 54 by 1929 and doubled again by $1938 .{ }^{44}$

Turkish officials generally embraced international integration throughout the interwar decades. Not only did the young Republic inherit the international memberships of the Ottoman Empire, the government also agreed to join new ones. In 1924, only one year after the founding of the new Turkey, Turkish politicians joined several newly created international bodies, among them humanitarian organizations like the League of Red Cross Societies and the Save the Children Union, as well as technical organizations like the International Railway

five years. As regards sanitation, Turkey agreed to exchange relevant health information with international partners. The government also had to accept the internationalized status of the Straits as well as certain economic constraints. Treaty of Lausanne, in The Treaties of Peace, 1919-1923, ed. Lawrence Martin (New York, Carnegie Endowment for International Peace: 1924).

${ }^{41}$ Glenda Sluga, Internationalism in the Age of Nationalism (Philadelphia: University of Pennsylvania Press, 2013), 9.

42 Madeleine Herren et al., LONSEA - League of Nations Search Engine, Heidelberg/Basel, 20102017, http://www.lonsea.org.

${ }^{43}$ Zara Steiner, The Lights that Failed: European International History 1919-1933 (Oxford: Oxford University Press, 2005), 368.

${ }^{44}$ Since membership data is not available for all the international organizations listed in LONSEA, the number of organizations in which Turkey participated is only the minimum. 


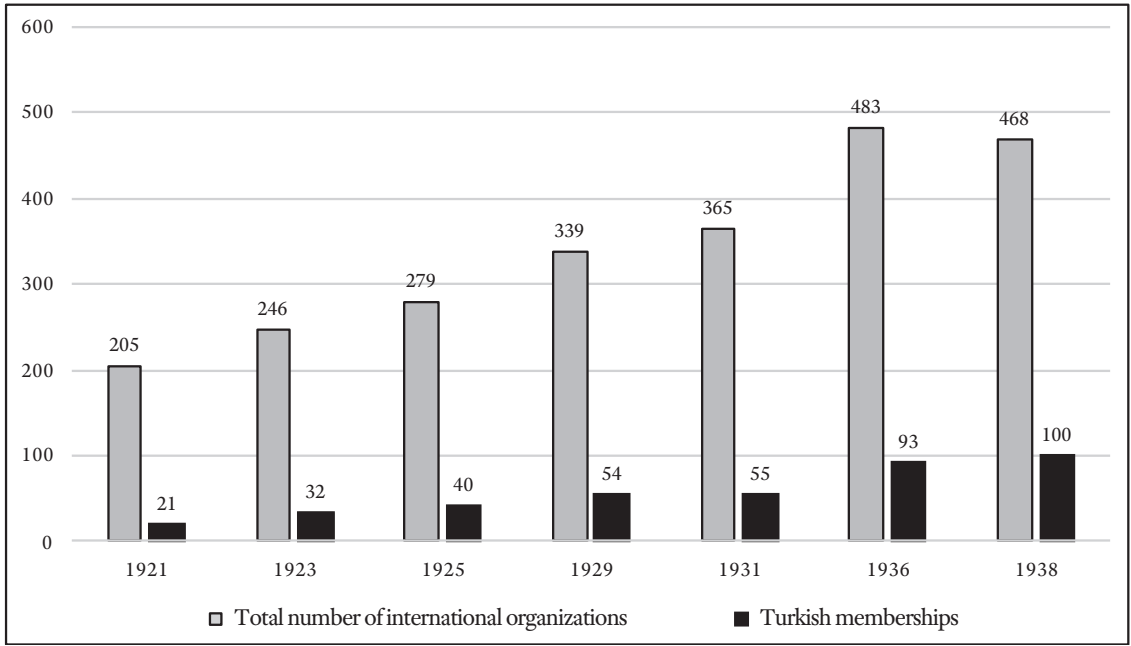

Figure 1: Turkey in International Organizations, 1921-1938

Union. Further accessions to membership in the 1920s included the International Chamber of Commerce, the International Council of Scientific Agriculture, the International Institute of Sociology and Social Reform, the International Touring Association and the International Association of Museum Officials. ${ }^{45}$ These few examples alone illustrate the range of policy areas, from transport, the economy, and science to national culture, which the new republic's elite was seeking to modernize.

At the same time, Turkish relations with the League and its Secretariat grew slowly. On the one hand, rapprochement was a necessity. Certain stipulations in political and humanitarian agreements involved the League and thus prompted communication by Ankara with Geneva, in particular with the League's Political Section, Minority Section, and the High Commissioner for Refugees. ${ }^{46}$ Besides, Turkish officials freely sought expertise from the Secretariat, especially from the Health Section and the International Labour Organization, in order

45 Data based on LONSEA.

${ }^{46}$ Mads Drange, Supervisor, Facilitator and Arbitrator. A Study of the Involvement of the Minority Section of the League of Nations in the Forced Population Exchange between Greece and Turkey in 1923 (M.A. thesis, University of Oslo, 2017); Keith David Watenpaugh, "The League of Nations' Rescue of Armenian Genocide Survivors and the Making of Modern Humanitarianism, 1920-1927," American Historical Review 115, No. 5 (2010): 1315-1339, doi: 10.1086/ahr.115.5.1315. 
to build up their national institutions. What is more, they seemed ready to join the League officially. At the Lausanne Conference 1922/23, the British delegate, Lord Curzon, pressured the Turkish delegation to finally take a stand and join the organization. In response, the Turkish delegate and Foreign Minister, İsmet (İnönü) Pasha, assured Curzon that "Turkey would be happy to enter the League of Nations upon the conclusion of peace." ${ }^{47}$ Both İsmet Pasha and the government back in Ankara agreed with that. ${ }^{48}$ They sent two Turkish delegates to the League Secretariat in order to obtain information about the organization on the spot. ${ }^{49}$ In January 1923, İsmet Pasha was expecting an official invitation from the British government to join the League at any time and discreetly consulted a British conference delegate as to how soon Turkey could do so. ${ }^{50}$ Later, in November, a Foreign Office official and Turkey's former Consul in Geneva, Cemil Selman (Tiyenşey), sent a confidential letter to League Secretary-General Eric Drummond inquiring about how much Turkey would be expected to pay in membership fees. ${ }^{51}$ In short, in 1923-24, Turkish membership in the League seemed to be imminent to all sides involved.

The League Secretariat was following the situation closely. In the course of postwar peacemaking, its members had proved willing enough to help realize the European powers' imperialistic designs on Turkey by means of promoting its internationalization. In 1919, Secretary-General Drummond and his staff even supported the Allied plan to separate Istanbul from Turkey. He proposed to put the city under League protection, thus catering to British interests. ${ }^{52}$ Even when the negotiations in Lausanne put an end to a broad scheme for imperialist internationalization, Secretariat members were eager to suggest compensations for the loss of European control over Turkish affairs. The League's Health Director, Ludwik Rajchman, thought that the League should send international medical advisers to Turkey to substitute for direct control

47 Territorial and Military Commission. Minutes of the Fifteenth Meeting, December 14, 1922, in $L C R, 221$.

48 İsmet Pasha to Hüseyin Rauf, December 14, 1922, in Lozan Telegraflart I, 215-216.

49 İsmet Pasha to Eric Drummond, December 6, 1922; reply by Eric Drummond, December 9, 1922, League of Nations Archives, Geneva (hereafter LONA), R1596 40-25113-24661.

50 İsmet Pasha to Mustafa Kemal Pasha, January 26, 1923, Başbakanlık Cumhuriyet Arşivi (Republican Archives Ankara), 30.10.0.0, 218.472.29; Nevile Henderson to James Ramsay MacDonald, July 26, 1924 (FO E 6425/5281/98), in British Documents on Foreign Affairs. Reports and Papers from the Foreign Office Confidential Print II (hereafter BDFA II), Vol. 30, ed. Bülent Gökay (Bethesda: University Publications of America, 1997), 202-204.

51 Cemil Selman to Pierre Comert, November 10, 1923, LONA, R1596-40-32191-24661.

52 Eric Drummond to Philip Kerr, December 13, 1919, LONA, R564-11-2432-2432. 
by the Supreme Council of Health. ${ }^{53}$ Similarly, Helmer Rosting, who was a high-ranking official in the Secretariat's Minority Section, discussed ways the League could redefine and effectively continue the privileges formerly granted to Europeans and Americans by the Capitulations, by extending the scope of the Minority Treaties. ${ }^{54}$ Both Rajchman and Rosting explored internationalist-friendly loopholes that would continue European influence in Turkey. They did so, however, within the limitations imposed by Turkish sovereignty, which they now had to accept.

The Secretariat soon adapted to the conditions created by Lausanne. It worked to forge stronger ties with Turkey and achieve its full membership. ${ }^{55}$ For that purpose, the League's Information Section decided to hire a Turkish assistant to act as go-between with Turkish government officials. He was expected to read the press and report on attitudes in Turkey toward the League. Ziya Hüsnü, who had studied in Belgium and Switzerland and worked as a correspondent for an Istanbul newspaper in Geneva, became the Secretariat's freelance "liaison officer for Turkey" from 1923 to $1934 .{ }^{56}$ At the same time, he was the Geneva correspondent of the newly founded Turkish state press agency, Anadolu Ajansı. With his influential role as a journalist and his familiarity with both the international milieu in Geneva and Turkish elite circles, he made an ideal intermediary for Geneva, Ankara, and the Turkish public. Turkish officials welcomed his connections and considered his journalistic activities a positive factor in strengthening public interest in the League in Turkey. In May 1924, the Turkish Consul in Geneva asked Drummond to provide Hüsnü with a permanent position, arguing that he could play an important role in Turkey's accession to the League, which he saw as soon to be realized. ${ }^{57}$

What might seem contradictory at first - Turkey's enthusiasm for internationalization and its rejection of imperialistic international structures - was actually a careful balancing act between international entanglements and national sovereignty. Again, international health cooperation serves as an example. As

53 Ludwik Rajchman, Memorandum, September 22, 1923, LONA, R1599 40-30417-28/80.

${ }^{54}$ Helmer Rosting, Report on a meeting with Aliçe Harun, November 22, 1922, LONA, R1596-4024661-24661.

55 Egon F. Ranshofen-Wertheimer, The International Secretariat. A Great Experiment in International Administration (Washington: Carnegie Endowment for International Peace, 1945), 358; Francis Paul Walters, A History of the League of Nations, 2nd edition (London: Oxford University Press, 1960), 561-562.

56 Gwenllian Vera Ward to Jean Henri Bieler, July 4, 1924, LONA, Zia Husni, Personnel File. Information on Ziya Hüsnü in this paragraph are based on his personnel file.

57 Ahmet Rüştü to Eric Drummond, May 22, 1924, LONA, Zia Husni, Personnel File. 
previously mentioned, the Turkish delegation at Lausanne had opposed the continuation of the Istanbul Supreme Council of Health. They rejected eurocentrism and European scientific superiority, arguing that Istanbul was no more of an epidemiological threat than Marseille or Genoa, and that Turkey itself had sufficiently qualified health experts who could take over the fight against epidemics. ${ }^{58}$ The Turks' insistence on their own autonomous health policies marked the beginning of renewed but now self-determined internationalization. Already in late 1923, Turkish authorities asked Rajchman, as Director of the Secretariat's Health Section, for expertise and help to expand the Turkish national health services. ${ }^{59}$ Rajchman, somewhat paternalistically, considered sending foreign medical advisers to Turkey, but he ultimately acknowledged the Turks' autonomy. He admitted that "strengthening of the sanitary administration of a country is the surest means of combatting epidemics in the long run." 60

In mid-1924, a British diplomat showed a keen understanding of Turkish sensitivities towards international cooperation. He spoke of two conflicting motives in Ankara: securing a strong nation-state on the one hand, and internationalizing it on the other. He noted that the Turks had recently refused to participate in the Conference of Naval Experts, but had willingly taken part in the Conference on Communications and Transit. Both conferences were held under the auspices of the League. One addressed disarmament, the other international transport and traffic. In his view, Turkey's participation in the politically less sensitive Transit Conference signaled its fundamental desire for international alignment, but its refusal to participate in a conference on international disarmament stemmed from its "unwillingness to get entangled in anything which might tend to hamper her freedom to develop her armed forces." ${ }^{61}$ Military strength is certainly the most forceful expression of sovereignty, but guarding national sovereignty also shaped Turkey's internationalization policy in other areas. In sum, the Kemalist approach towards international organization was neither isolationist nor unconditionally integrationist. It is better described as a balancing act aimed at the symmetric internationalization of the sovereign nation-state in the making. ${ }^{62}$ This had two contradictory effects. While national sovereignty was

${ }^{58}$ Economic and Financial Commission. Minutes of the Fifth Meeting, January 27, 1923, in LCR, 595-597.

${ }^{59}$ Riza Nur to Ludwik Rajchman, September 6, 1923, LONA, R853 12B-31283-26249.

${ }^{60}$ Ludwik Rajchman, Memorandum, September 22, 1923, LONA, R1599 40-30417-28/80.

${ }^{61}$ Nevile Henderson to James Ramsay MacDonald, July 26, 1924 (FO E 6425/5281/98), BDFA II, Vol. 30, 202.

62 The end of international control did not render Turkey uninterested in foreign affairs. On the contrary, having regained formal sovereignty in 1923, the Turkish government started using their 
a prerequisite for equal international cooperation, the national interest tended to alienate Turkey from some kinds of international engagements, for example, from international efforts toward disarmament and the League of Nations' Minority System. ${ }^{63}$

\section{The Question of (Non-)Membership Reconsidered}

The initial optimism about imminent Turkish membership in the League suddenly nosedived in 1925-26 when the League took up the Mosul Question and decided it in favor of the British Government. Since Mosul had been part of the territorial claims of the National Movement, the League's decision irritated the Turkish public. A British diplomat in Turkey, Reginald Hoare, reported that both the press and the government felt that the League "was the debauched handmaid of Great Britain."64 Existing research identifies the Mosul Question as the main reason for Turkey's relatively late accession to the League. ${ }^{65}$ This is undoubtedly true, but I see fit to add two observations.

First, it might be more accurate to say that the League's decision on Mosul was not so much the main reason for Turkey's hesitancy to join the League, but rather it confirmed the Kemalists' general mistrust of the power asymmetries in international organizations. Ever since Turkey's foundation, its leaders had not only voiced their intention to join the League, but also their discontent regarding the League's asymmetric structure. The Turkish government, the press, and parliamentarians in Ankara all criticized the Council - the League's decision-making body - in particular. ${ }^{66}$ Foreign diplomats assumed quite rightly

increased bargaining power in order to achieve favorable trade deals and other international agreements e.g. those relating to international disarmament and the opium trade. See William B. McAllister, Drug Diplomacy in the Twentieth Century. An International History (London: Routledge, 2000), 37, 67, 92; and Yahya S. Tezel, Cumhuriyet Döneminin İktisadi Tarihi (1923-1950) (Ankara: Yurt Yayınlar1, 1986), 139-143, 148-150.

${ }^{63}$ Since it perceived international efforts to protect minorities as a vestige of nineteenth century imperialist interventionism as well as a threat to its goal of homogenizing its population, the Turkish government remained uncooperative. See Lerna Ekmekçioğlu, "Republic of Paradox. The League of Nations Minority Protection Regime and the New Turkey's Step-Citizens," International Journal of Middle East Studies 46, No. 4 (2014): 657-679, doi: 10.1017/S0020743814001007. Nationalist policies in the economic sector were another reason for its alienation, see Pamuk, Uneven Centuries, 195-196.

${ }^{64}$ Reginald Hoare to Austen Chamberlain, March 31, 1926 (FO E 2189/2189/44), BDFA II, Vol. 30, 396-397.

65 Barlas, "Milletler Cemiyeti'nde Türkiye," 98; Turkey and the United Nations, 19.

${ }_{66}$ TBMM Zabut Ceridesi (Proceedings of the Grand National Assembly of Turkey) 4/1, Meeting 2, Vol. 1 (May 9, 1931), 25; TBMM Zabut Ceridesi 4/3, Meeting 28, Vol. 2 (July 15, 1931), 133. Other 
that the Mosul decision destroyed Turkey's trust in the Geneva organization. ${ }^{67}$ Nevertheless, Turkish officials did not fully retreat from their plan to join the League. Instead, they started to negotiate.

After 1926, Turkish officials repeatedly used public events and their meetings with diplomats and members of the League Secretariat to announce that a seat on the League's Council was the sine qua non ${ }^{68}$ for their accession. ${ }^{69} \mathrm{In}$ an interview with the press in Berlin in spring 1929, Tevfik Rüştü (Aras), Turkey's Foreign Minister from 1925 to 1938, declared that Turkey was prepared to participate in the work of the League. "We will, however, certainly not seek admission to the League," he added, "until complete equality of the rights of nations is established." 70 Behind closed doors, however, Tevfik Rüştü admitted to Secretary-General Drummond that he himself desired League membership. Even so, he explained, the League's image with the Turkish public and Parliament was still suffering from the Mosul decision. He therefore needed a convincing argument - the guarantee of a seat on the Council. ${ }^{71}$ In the 1920 s, Turkey's membership was largely a question of achieving a relatively equal starting position with the dominant powers in an asymmetric organization.

Second, we should be careful not to mistake postponement of membership for a full retreat from internationalism. Existing scholarship suggests that the Mosul decision led Turkey to distance itself from the League and conclude a renewed Treaty of Friendship with the Soviet Union. ${ }^{72}$ While that is true with regard to Turkey's reaction on the diplomatic level, it overlooks that its reaction on the level of internationalization was quite different. After 1925, the Kemalists did not turn to the Communist International, but to an organ of the League:

countries at the periphery of international power also criticized the League and its unequal internal structure. See Fischer, Die Souveränität der Schwachen, 270-271; Sally Marks, "The Small States at Geneva," World Affairs 157, No. 4 (1995): 191-196.

67 Nevile Henderson to James Ramsay MacDonald, July 26, 1924 (FO E 6425/5281/98), BDFA II, Vol. 30, 203.

${ }^{68}$ George R. Clerk to Austen Chamberlain, June 8, 1927 (FO E 2614/17/44), BDFA II, Vol. 31, 10.

${ }^{69}$ Statement cited in Ronald Lindsay to Austen Chamberlain, June 9, 1926 (FO E 3624/3624/44), BDFA II, Vol. 30, 403-404; George R. Clerk to Arthur Henderson, October 10, 1929 (FO E 5266/5266/44); William Edmonds to Arthur Henderson, December 18, 1929 (FO E 6691/5266/44), BDFA II, Vol. 31, 336, 359.

70 Passages from the interview quoted in Horace Rumbold to Austen Chamberlain, April 24, 1929 (FO E 2118/92/44), BDFA II, Vol. 31, 312-313.

${ }^{71}$ Discussed in George R. Clerk to Austen Chamberlain, April 30, 1928 (FO E 2381/43/44), BDFA II, Vol. 31, 176; George R. Clerk to Arthur Henderson, January 14, 1930 (FO E 323/323/44), BDFA II, Vol. 32, 1 .

72 Turkey and the United Nations, 34. 
the International Labour Organization (ILO). ${ }^{73}$ It is remarkable that, at the very same time Turkish relations with the League turned sour, the Turks' relationship with the International Labour Organisation and its office in Geneva gained momentum. In September 1925, Albert Thomas, the director of the International Labour Office (the ILO bureau), met with the Turkish Foreign Minister and his Berne envoy, Mehmet Münir (Ertegün). Now that accession to the League of Nations had become somewhat hypothetical, Thomas concluded that relations between his office and Ankara should play an important role. Although Turkey did not have ILO membership, its relations were handled in more unofficial ways "under the pretext of field studies or information." 74 The next spring, a delegation of the International Labour Office paid a visit to Ankara and Istanbul in order to learn about the socioeconomic policies of the Turkish government and to set the course for future relations. The lead delegate, Fernand Maurette, reported that the mere mention of the League made his hosts angry. As a result, Maurette made every effort to stress the ILO's autonomy from the League. The Ministers he met were eager to cooperate with the ILO. Foreign Minister Tevfik Rüştü, Maurette said, even inquired about the possibility of joining the ILO independently of the League. ${ }^{75}$

The visit turned out to be a success for both sides. It marked the start of a mutual information exchange and the participation of Turkish observers in the Labour Conferences. The Istanbul correspondent of the newspaper Le Temps, who followed the events, wrote an enthusiastic letter to Albert Thomas. He encouraged the ILO, because "it is more free to act in Turkey than the L.o.N.," to take over the task of establishing itself "in Turkey in the spirit of Geneva"76 and make the "new Turkey" part of the international alliance for progress. For the Turkish government, intensified relations with the ILO served as more than just an ersatz liaison with the League. Rather, the ILO's mission dovetailed with the Kemalists' socioeconomic agenda in the 1920s. Broadly speaking, this was a mixture of capitalism and state control. It was an agenda aimed at building up a strong national economy and overcoming potential class strife through national solidarity. The ILO, which promoted the solution of social questions within the capitalist system, was ideologically compatible with the solidarist - and

73 On the ILO, see Antony Alcock, History of the International Labour Organisation (New York: Palgrave Macmillan, 1971).

${ }^{74}$ Albert Thomas, Report about the Meeting, September 21, 1925, International Labour Organisation Archives, Geneva (hereafter ILOA), CAT 5-73/1/1.

75 Fernand Maurette, Report about the Mission to Turkey, March 24, 1926, ILOA, CAT 5-73/1/3.

76 Paul Gentizon to Albert Thomas, March 25, 1926, ILOA, CAT 5-73/1/3. 
anti-communist - leanings of the Turkish government. ${ }^{77}$ As shown before, the Turkish approach to international organizations can be understood as an attempt to balance out asymmetric power relationships. At the same time, as the ILO example highlights, it implied a policy of openness to international ventures that were consistent with the Turkish government's domestic agenda.

Cooperation with the Geneva-based international organizations remained a central goal of the Kemalists throughout the 1920s, even though they did not seek actual membership. The Secretariat's sections and different fields of cooperation, as well as the ILO Bureau, provided the Turkish government with an indirect path to liberal internationalism. This was in line with Turkey's cautious, balanced internationalization strategy, because it enabled the Turks to participate in the League without bowing to their internal hierarchies. In particular, the ILO's relative autonomy from the League allowed the Turkish government to become involved with it, even shortly after the Mosul dispute, without abandoning its ostentatiously critical attitude toward the League. In the late 1920s, relations with the ILO slowly intensified in tandem with an increase in Turkey's cooperation with the League. The Turkish government ratified several conventions initiated by the League and Turkish delegates participated in important League conferences, including the World Economic Conference (1927). ${ }^{78}$ "Little by little she is drawing nearer," 79 commented the British Ambassador in Ankara on Turkey's relationship with the League during that time. In 1929, a fellow diplomat remarked that Turkey's "desire for westernisation, which is at the root of her internal policy, carries her towards Geneva." ${ }^{00}$ As the next chapter reveals, there was in fact a common denominator of westernization and internationalization in the Kemalist mentality.

\section{Nation-building as an Internationalization Strategy}

As I have tried to show, internationalization was just as important to the Kemalist leaders as preserving Turkey's sovereignty within internationalist

\footnotetext{
77 Ahmad, "Political Economy," 151-152; On solidarism in Turkey, see Ertan Aydın, "Peculiarities of Turkish Revolutionary Ideology in the 1930s. The Ülkü Version of Kemalism, 1933-1936," Middle Eastern Studies 40, No. 5 (2004), 55-82, here 66-67, doi: 10.1080/0026320042000265675.

78 Cf. Société des Nations, L'œuvre de la Société des Nations en matière de conventions internationales. Signatures, ratifications et adhésions concernant les Accord et Conventions conclus sous les auspices de la Société des Nations. Vingt et unième liste, C. 25. M. 251943 V. Annexe, Genève le 10 Juillet 1944.

${ }^{79}$ George R. Clerk to Arthur Henderson, October 10, 1929 (FO E 5266/5266/44), BDFA II, Vol. 31, 336.

80 William Edmonds to Arthur Henderson, December 18, 1929 (FO E 6691/5266/44), BDFA II, Vol. 31,359 .
} 
structures. Stressing the link between the Kemalists' attitudes and the Ottoman experience of semi-colonial status vis-à-vis the western world, I suggest understanding the desire for symmetric internationalization as the basic rationale for Kemalist policies. It explains their determined effort to avoid asymmetric entanglements as well as their cautious cooperation with international organizations. However, it does not explain their later positive embrace of renewed internationalization. This chapter, therefore, discusses how internationalization was in fact a fundamental goal of the Kemalists in the first place. It highlights the structural and ideological connections between Turkish nation-building and liberal, i.e. Wilsonian, internationalism. One explanation for this, I think, can be found in the work of Ziya Gökalp.

Ziya Gökalp (1876-1924) is widely regarded as the key thinker of Turkish nationalism both in the late Young Turk times and in the time of the early Republic. His theories provided both inspiration and academic cachet for the Kemalist social engineering that transformed the multiethnic Empire into a secular nation state. Over the decades, scholars from different intellectual backgrounds have evaluated Gökalp's ideas. Some of them portray Gökalp as a promoter of authoritarianism and jingoism. ${ }^{81}$ Genocide scholars have accused him of ideological contributions that justified systematic ethnic exclusion and violence in Anatolia. ${ }^{82}$ By contrast, other scholars stress his left-leaning concept of solidarity. ${ }^{83}$ Still others interpret his synthesis of the Turkish Muslim identity and modernization as a postcolonial case of "multiple modernity." ${ }^{4}$ It is fair to say that Gökalp was all that. His figure is just as ambiguous as the Turkish modernity he championed.$^{85}$ What most prominent works about him share in common, however, is a disregard for his conceptions of internationalism. ${ }^{86} \mathrm{His}$ most ardent

${ }^{81}$ Most prominent is Uriel Heyd, Foundations of Turkish Nationalism. The Life and Teachings of Ziya Gökalp (London: Luzac and Harvill Press, 1950), 169.

82 E.g. Uğur Ümit Üngör, "Seeing like a Nation-state. Young Turk Social Engineering in Eastern Turkey 1913-50," Journal of Genocide Research 10, No. 1 (2008): 15-39, here 23, doi: $10.1080 / 14623520701850278$.

83 Taha Parla, The Social and Political Thought of Ziya Gökalp 1876-1924 (Leiden: Brill, 1985).

84 Andrew Davison, “Ziya Gökalp and Provincializing Europe," Comparative Studies of South Asia, Africa and the Middle East 26, No. 3 (2006): 377-390, doi: 10.1215/1089201x-2006-020; Jonathan A. Grant, "Crossing the Eastern Divide: Western Civilization and Islam in the Views of Chaadaev and Gökalp," History Compass 3, No. 1 (2005): 1-7, doi: 10.1111/j.1478-0542.2005.00127.x.

85 A concise summary of the different elements in Gökalp's thinking appears in Hamit Bozarslan, “M. Ziya Gökalp," in Modern Türkiye’de Siyasî Düşünçe 1: Cumhuriyet’e Devreden Düşünce Mirası. Tanzimat ve Meşrutiyet'in Birikimi (Istanbul: İletişim, 2001), 314-319.

${ }^{86}$ Notable exceptions are Taha Parla's book as well as a short paragraph in Banu Turnaoğlu, The Formation of Turkish Republicanism (Princeton: Princeton University Press, 2017), 170. 
critic even claimed that Gökalp lacked "ideals of humanity and international co-operation." ${ }^{87}$ In fact, the contrary is true: Gökalp had a very clear idea of international cooperation even if it was an anti-individualistic and nationalistic one. Although I cannot delve deeply into his theories here, I hope to show that his thoughts on nationalism and modernity are bound up with a distinctive approach to internationalism.

In 1923, the founding year of the Republic, Gökalp published Türkçülüğün Esasları (The Principles of Turkism), which is his main theoretical and ideological work. There he articulated his belief that Turkey lagged "far behind the European nations" and should make every effort "to catch up with them in civilization." 88 His view is characteristic of that of the Young Turk elite, who developed a repertoire of progressive, positivist, social Darwinist ideas. ${ }^{89}$ However, similar to some of his Young Ottoman forerunners like Namık Kemal and Ziya Pasha, Gökalp warned his countrymen not to mistake the endeavor to catch up with European civilization for cultural assimilation..${ }^{90}$ Inspired by French and German sociology, in particular by Ferdinand Tönnies's concepts of gesellschaft and gemeinschaft, Gökalp insisted that there is a fundamental difference between civilization (medeniyet) and culture (hars). ${ }^{91}$ In his definition, a civilization is a group of nations sharing - via imitation and exchange - similar social structures, concepts, technologies, and systems of knowledge. Similar to Tönnies' definition of gemeinschaft, he defined culture as not only a functional form of socialization, but a natural community based on strong feelings of belonging. Gökalp defined culture as something essentially national that varies from nation to nation. Hence, he concluded, Turkey should take a dual path to modernity: it should adopt the institutions of "European civilization" and the model of the secular nation state, but at the same time cherish a distinct national culture based on a Turkish and Muslim identity. Gökalp's cultural essentialism reveals the influence of idealistic thinkers like Johann Gottfried Herder, who relativized

\footnotetext{
${ }^{87}$ Heyd, Foundations, 169.

88 Ziya Gökalp, The Principles of Turkism, transl. by Robert Devereux (Leiden: Brill, 1968), 75. Modern Turkish version: Ziya Gökalp, Türkçülüğün Esasları (Istanbul: Millî Eğitim Basımevi, 1970), 109-110.

89 Şükrü M. Hanioğlu, Preparation for a Revolution. The Young Turks 1902-1908 (New York: Oxford University Press, 2001), chapter 10.

90 Gökalp, Türkçülüğün Esasları, 110. On the Young Ottomans, see Christiane Czygan, "Reflections on Justice: A Young Ottoman View of the Tanzīmāt," Middle Eastern Studies 46, No. 6 (2010): 943-956, doi: 10.1080/00263200903445714.

${ }^{91}$ Ferdinand Tönnies, Gemeinschaft und Gesellschaft. Abhandlung des Communismus und des Socialismus als empirische Culturformen (Leipzig: Fues, 1887).
} 
the cosmopolitan impetus of the Enlightenment by stressing the people's unique development. ${ }^{92}$

We need to understand Gökalp's conceptual distinction between culture and civilization in order to make sense of his notion of internationalism (beynelmileliyet, also beynelmileliyetçilik). "Modern civilization," he wrote in 1913, "is on its way to create a new internationality." 93 The novelty of this internationality, as he saw it, was its secular and scientific character, which opened it up to non-Christian nations like Japan and Turkey, so long as they agreed on the same civilizational tenets. In Gökalp's view, internationalism coincided with European civilization. In his later work "Principles of Turkism," published after the League had come into existence, he refined his thoughts on the matter, fitting internationalism into his dual concept of civilization and national culture. Much the same as the "nation is the sum total of individuals who share a common culture," he wrote, internationalism is "the sum total of nations which share a common civilization." ${ }^{4}$ "Thus, any particular internationality," he concluded, "includes a common civilization shared by all member nations, as well as a collection of the national cultures of those nations." 95 Gökalp considered the international order (and the League of Nations in particular) to be both essentially national and an institutional expression of European civilization. Hence, he declared internationalism to be the most natural setting for western-oriented Turkish nation-building: "This means that when we enter European civilization, we will inherit ... an international civilization. ${ }^{96}$ In his eyes, Turkish nation-building was compatible with, even congenial to internationalism, because both of them were built upon European civilization and nationalism. "There is, however, no irreconcilable contradiction between Turkism and internationalism. Every Turkist [Türkçü, Turkish nationalist] is simultaneously an internationalist, because each of us lives two social lives, one national, the other international."97

Gökalp's view of liberal internationalism as the alter ego of Turkish nationalism was widely shared among the Kemalist elite. It was popular in the emerging social sciences, in school curricula, in press coverage of international politics,

92 On Gökalp and romantic idealism, see Mihran Dabag, "Knowledge, Order and Formative Violence in the Middle East: On the Relation between Islam and the Nation State from the Ottoman Empire to the Present," in Disasters of War: Perceptions and Representations from 1914 to the Present, ed. Steffen Bruendel and Frank Estelmann (Paderborn: Wilhelm Fink, 2019), 33-56, 51.

93 Ziya Gökalp, “Üç Cereyan,” in Türkleşmek, İslamlaşmak, Muasırlaşmak (Istanbul, 1949), 13.

94 Gökalp, Principles, 73 (Gökalp, Türkçülüğ̈̈̈n Esasları, 106).

95 Ibid.

96 Ibid. (Gökalp, Türkçülüğün Esasları, 107). Italics added.

97 Ibid., 74 (Gökalp, Türkçülü̈̆̈̈n Esasları, 108). 
and in the Foreign Ministry itself. ${ }^{98}$ In a session of Parliament, Foreign Minister Tevfik Rüştü declared that the League of Nations could almost be regarded "our own idea." 99 The perceived need for modernization, nationalization, and Europeanization - a legacy of the Young Turks - was deeply embedded in postwar Turkish nation-building and in Kemalism. ${ }^{100}$ The fact that the Kemalists identified ideologically with liberal internationalism had a profound impact on their stance towards "alternative" kinds of internationalism. Prior to the consolidation of the Republic of Turkey in 1923, Turkish nationalists participated in conferences held by the Socialist International and the Comintern and engaged in pan-Turkic and pan-Islamic conferences and networks. ${ }^{101}$ The Ankara government itself hosted pan-Islamic meetings and sent an official delegation to the Communist International's 1920 Congress of the Peoples of the East in Baku. ${ }^{102}$ However, such internationalist ventures were only temporary and pragmatic in nature. They supported the National Movement's short-term goal of preventing the implementation of the Sèvres Treaty.

The Kemalists' actual ideological distance from such alternative forms of international organization showed itself in their severe control and oppression of communists, political pan-Islamists, and irredentist pan-Turkists in the 1920s. ${ }^{103}$ The famous British historian Arnold Toynbee, who attended the Lausanne Peace Conference and also undertook a journey to Turkey, put it like this: "A definite and limited Turkish Nationalism is in the ascendant, while Pan-Islamism and

98 Gökalp's pupil, Necmettin Sadık (Sadak), who succeeded Gökalp as Chair of Sociology in Istanbul in 1920, also happened to be a prominent newspaper editor, the author of an influential school textbook on society and politics, and Turkey's delegate to the League of Nations Assembly from 1932. See "Necmeddin Sadak," in Dışişleri Bakanlı̆̆ı 1967 Yıllı̆̆ı, ed. Hâmid Aral (Ankara, 1967), World Biographical Information System ID Q70197; Necmeddin Sadak, Sosyoloji (Istanbul 1938).

99 TBMM Zabut Ceridesi (Proceedings of the Grand National Assembly of Turkey) 4/3, Meeting 28, Vol. 2 ( July 15, 1931), 133.

100 Erik-Jan Zürcher, The Young Turk Legacy and Nation Building: From the Ottoman Empire to Atatürk's Turkey (London: I.B. Tauris, 2010).

${ }^{101}$ Carolin Liebisch, "Defending Turkey on Global Stages: The Young Turk Reşit Saffet's Internationalist Strategy in 1919," New Global Studies 10, No. 3 (2016): 217-251, doi: 10.1515/ngs-20160022; Alp Yenen, "The Other Jihad: Enver Pasha, Bolsheviks, and Politics of Anticolonial Muslim Nationalism during the Baku Congress 1920," in The First World War and its Aftermath: The Shaping of the Middle East, ed. T. G. Fraser (London: Gingko Library Press, 2015), 273-293.

102 Ayla Göl, Turkey Facing East: Islam, Modernity and Foreign Policy (Manchester: Manchester University Press, 2013).

103 Cemil Aydin, “The Muslim World' Question during the Interwar Era Global Imaginary, 19241945," New Global Studies 10, No. 3 (2016): 349; Bülent Gökay, Soviet Eastern Policy and Turkey, 1920-1991: Soviet Foreign Policy, Turkey and Communism (London: Routledge, 2006), 41-46; Jacob M. Landau, Pan-Turkism. From Irredentism to Cooperation, 2nd edition (London: Hurst and Company, 1995), 74-80. 
Pan-Turanianism are markedly out of fashion." ${ }^{104}$ He stressed his belief that "The West, and not Russia, remains their [the Kemalists'] ideal; the western comity of nations, not the Third International, is the society into which they are seeking an entry." 105 From the outset, the Kemalists' cooperation with the Soviets, which continued throughout the interwar decades, was pragmatic in the sense that it served the reassertion of Turkish sovereignty and national interests, but did not share the Soviet vision of an ideal communist society. ${ }^{106}$ As regards their own vision of the ideal socioeconomic structure, the Kemalists built on the Tanzimat tradition, which respected, but did not blindly imitate, the western European model of "civilization." 107

Considering the ideological connections between Turkish nationalism and liberal internationalism, it seems plausible that not only particular developmental objectives were behind the Kemalists' decision to cooperate with western organizations, but also their general drive toward nationalization, modernization, and "civilization." Of course, when government officials asked the League Secretariat for medical expertise or the ILO for information on socioeconomic topics, they mainly did so in order to modernize their state institutions. However, modernization was part of a broader scheme aimed at becoming an equal partner in the community of modern states. The thought shared by the modernizing elites in the late Ottoman Empire and the Kemalist era was that building up a modern state was the surest means to thwart European imperialism. Nation-building, the logic went, would forge a modern, homogeneous nationstate, which would then be recognized as a part of civilization and whose sovereignty would be respected. In the same way, successful nation-building would immunize Turkey against the imperialistic potential latent in internationalism. The consolidation of a strong nation-state and its international recognition were, in the eyes of many, an indispensable precondition for internationalization.

"(W)hat advantage will we gain by entering the League of Nations until we have definitely entered European civilization?” Gökalp asked. He explained that a "nation that other nations desire to subject to political interventions and capitulations is a nation considered to be outside that civilization." 108 While he saw liberal internationalism as the natural choice for the Turks, he - as well

\footnotetext{
104 Arnold J. Toynbee, "Angora and the British Empire in the East," The Contemporary Review 123 (January 1923): 684.

105 Ibid., 688.

106 Göl, Turkey Facing East, 174-175.

107 Pamuk, Uneven Centuries, 168-169.

108 Gökalp, Principles, 47 (Gökalp, Türkçülü̈̆̈̈n Esasları, 66).
} 
as the Kemalist elite - found fault with the League for not living up to Wilsonian principles. Foreign Minister Tevfik Rüştü spoke of the League as two different things, an ideal and a real organization, and bemoaned the discrepancy between the two. In his and Gökalp's view, Turkish nationalists were in fact better internationalists, because unlike European governments, they truly cherished the ideals of the League. ${ }^{109}$ As a result, the Kemalists chose not to abstain from the League altogether, but to achieve a favorable position within the organization. ${ }^{110}$ In their eyes, this required that Turkey be recognized internationally as a civilized nation. Living up to the "standard of civilization" in the international community and becoming accepted as a modern state and a member of "European civilization" were the key goals of the Kemalists. Seen this way, the prominent reforms of the 1920s - from the Hat Reform to the adoption of the Swiss Civil Code - had more to do with international organizations than it may initially appear. In fact, one could say that reform contributed to the Kemalist internationalization strategy and its goal of equal, sovereign, balanced international integration. ${ }^{111}$

\section{Discussion: Intersecting Asymmetries and a Postcolonial Reading of International Organizations}

Researchers who advocate a postcolonial reading of international relations generally highlight the role of western hegemony in shaping the discourses and structures of international politics. They then investigate how actors at the peripheries of global power interacted within this setting. ${ }^{112}$ As regards the case of Turkey, such an approach delivers useful insights for expanding the

109 Ziya Gökalp, “Milletler Cemiyeti,” Cumhuriyet, July 26, 1922, in Ziya Gökalp, Makaleler IX: Yeni Gün, Yeni Türkiye, Cumhuriyet Gazetelerindeki Yazılar, ed. Şefket Beysanoğlu (Istanbul: Kültür Bakanlığı Yayınları, 1980), 134-137; Tevfik Rüştü's statement in TBMM Zabıt Ceridesi (Proceedings of the Grand National Assembly of Turkey) 4/3, Meeting 28, Vol. 2 (July 15, 1931), 133.

${ }^{110}$ Cf. Turkey and the United Nations, 18.

111 Yücel Bozdağlığlu, Turkish Foreign Policy and Turkish Identity (New York: Routledge, 2003), 51. Bozdağlığlu says, "The construction of a new identity through the Kemalist reforms provided the new political elite with the framework within which Turkish foreign policy was thenceforth to be formulated." His brilliant study stands out among the literature on Turkey's diplomatic history thanks to his constructivist approach and his emphasis on international organizations and cultural factors. However, the book does not cover the League and international organizations in the interwar period.

112 See the overview by Jan Wilkens, "Postcolonialism in International Relations," in Oxford Research Encyclopedia of International Studies (Oxford: Oxford University Press, 2017), 1-26, doi: 10.1093/acrefore/9780190846626.013.101. See also, Fabrice Argounès, "De l'usage des Subaltern studies en Relations Internationales," Dynamiques Internationales No. 1 (2009): 1-24. 
historiography of the country's internationalization. It shows that while Turkey's internationalization may have been driven by tactical concerns, multilateral constellations, and power interests, as well as by its developmental objectives, there is another dimension. Internationalization was also a strategy for dealing with European global hegemony.

As seen in the previous chapter, the Kemalist discourse of modernization as a sort of internal civilizing mission that would allow Turkey to "catch up" with "European civilization" was ingrained in their demand for symmetrical internationalization. The relation between Turkey and the League thus existed on a much deeper level than that of foreign affairs. Not only foreign policy, but the very process of building the nation was behind Turkey's participation in international organizations. ${ }^{113}$ The Kemalists' goal was to become part of "European civilization." They saw the League of Nations ideals (despite the shortcomings in their realization) as the institutional embodiment of that civilization. Nation-building aimed to transform Turkey into a "modern" nation-state that would be recognized as an equal and sovereign member of the international community. It was therefore an internationalization strategy, albeit an ambivalent one. It challenged the hierarchies of power that existed on the international level, but it also reinforced the power asymmetries within the new Turkish state, as discussed below.

Putting Turkey's internationalization in the 1920s into the context of imperialism and anti-imperialism is only half the story. The Kemalists' strong insistance on an ethnically exclusive form of nationalism imbued their approach to internationalism with an essentialist, nationalist, and anti-individualist spirit. Gökalp himself referred to his own conception of internationalism as the "antithesis of cosmopolitanism," 114 because he defined "a civilization" as constituted of national identities and not individual human beings. His interpretation tied in with that of his contemporaries, like the French sociologist Marcel Mauss and the Swiss international law expert Max Huber, who defined internationalism as the opposite of both cosmopolitanism and imperialism. ${ }^{115}$ The League represented a world order of national collectives, not global citizens. It respected

${ }^{113}$ Influential works highlighting the international dimension of the nation-building process are Martha Finnemore, National Interests in International Society (Ithaca: Cornell University Press, 1996); Connie L. McNeely, Constructing the Nation-State. International Organization and Prescriptive Action (Westport: Greenwood Press, 1995); Anne-Marie Thiesse, La Création des identités nationales, Europe XVIII ${ }^{e}-X X^{e}$ siècle (Paris: Seuil, 1999), 18, 284-285.

114 Gökalp, Principles, 73 (Gökalp, Türkçülüğün Esasları, 106).

115 Max Huber, "Beiträge zur Kenntnis der soziologischen Grundlagen des Völkerrechts und der Staatengesellschaft," in Jahrbuch des öffentlichen Rechts der Gegenwart 4 (1910): 128; Marcel 
the ultimately anti-cosmopolitan principle of the nation-state. Therefore it was acceptable to the Turkish nationalists. ${ }^{116}$ "Turkism," Gökalp explained, "cannot be reconciled with any system that rejects the principle of nation." The nationalist vision of Gökalp and the Kemalists by no means tolerated their country's heterogeneity. At its core lay an exclusive Turkish-Muslim identity, not an inclusive concept of citizenship. Throughout the 1920s, the government fostered a homogeneous national culture. ${ }^{117}$ This included suppressing the political opposition (communists, liberals, and reactionaries) as well as civil society activists like trade unionists. ${ }^{118}$ At the same time, Kemalism worked to physically homogenize the population via drastic means, such as the so-called population exchange with Greece, the denaturalization of the survivors of the Armenian genocide, and the forced assimilation of the Kurds. ${ }^{119}$ Creating a religiously, ethno-linguistically, and ideologically uniform nation was an integral part of the Kemalists' scheme for achieving a modern and sovereign state.

For future research, studies dedicated to the early history of Turkey's foreign policy vis-à-vis international organizations might find it fruitful to elaborate upon the already existing works about its minority politics and their international dimension. ${ }^{120}$ As Volker Prott argues in his book on the Politics of Self-Determination, local actors, confronted with the loss of territory after World War I, invoked their ethnicity in order to align their cause with the international discourse of national self-determination. ${ }^{121}$ Unlike Erez Manela, who considered Wilsonianism to be above all an anti-colonial moment, Prott

Mauss (1920), "La nation et l'internationalisme," in CEuvres 3: Cohésion sociale et divisions de la sociologie (Paris: Les Éditions de Minuit, 1994), 626-634, 629-630.

116 Eric D. Weitz, "From the Vienna to the Paris System. International Politics and the Entangled Histories of Human Rights, Forced Deportations, and Civilizing Missions," American Historical Review 113, No. 5 (2008): 1313-1343, doi: 10.1086/ahr.113.5.1313. See also, Sluga, Internationalism.

117 Yeşim Bayar, Formation of the Turkish Nation State, 1920-1938 (Basingstoke: Palgrave Macmillan, 2014).

118 Stefan Plaggenborg, Ordnung und Gewalt. Kemalismus, Faschismus, Sozialismus (München: O1denbourg, 2012), 164.

119 Üngör, "Seeing;" Sarah D. Shields, "Forced Migration as Nation-Building: The League of Nations, Minority Protection, and the Greek-Turkish Population Exchange," Journal of the History of International Law 18, No. 1 (2016): 120-145, doi: 10.1163/15718050-12340054.

120 E.g. Lerna Ekmekçioğlu, "Republic of Paradox: The League of Nations Minority Protection Regime and the New Turkey's Step-Citizens," International Journal of Middle East Studies 46, No. 4 (2014): 657-679, doi: 10.1017/S0020743814001007; Sarah D. Shields, Fezzes in the River: Identity Politics and European Diplomacy in the Middle East on the Eve of World War II (Oxford: Oxford University Press, 2011); Watenpaugh, "Rescue of Armenians."

121 Volker Prott, Politics of Self-Determination: Remaking Territories and National Identities in Europe, 1917-1923 (Oxford, Oxford University Press, 2016). 
stressed the ethnification of Wilsonianism and how it contributed to violence. Our understanding of the Turkish case, I would argue, needs to follow up on Prott's reading. The Kemalists' attachment to liberal internationalism and the ideal of a community of sovereign nation-states cannot be dissociated from their use of force to create a homogenous, centralized nation-state that marginalized ethno-religious minorities and the political opposition. The Republican government claimed ultimate authority not only over internal affairs, but also over the internationalization of the "new Turkey." By asserting political authority, it suppressed the activities of Turkish communists and pan-Islamists and thus stifled their opposing versions of internationalism. Pursuing drastic population policies, it also prevented national minorities from articulating their rights and protesting discrimination at the international level. ${ }^{122}$

"There was only one civilization ... and Turkey had to be a part of it in order to survive," Yücel Bozdağlıoğlu summarizes the Kemalists' ideological mindset. He adds that this policy "in turn led to the suppression of other identities, mainly ethnic and religious, and exclusion of them from the political process." 123 The downside of the Kemalist struggle for symmetrical integration into the international organization was the consolidation of a nation-state where the collective identity and sovereignty outranked the individual. Despite its numerous transnational activities, the League of Nations ultimately represented a system based on sovereign national entities that exercised political power over their populations. By acknowledging that the Kemalists were the elite of a highly centralized state who tried to force their interpretation of modernization, civilization, and internationalization on Turkish society, we encounter the limits of the postcolonial approach.

122 On the government's resistance to the League of Nations' minority rights regime see, Martin Scheuermann, Minderheitenschutz contra Konfliktverhütung? Die Minderheitenpolitik des Völkerbundes in den Zwanziger Jahren (Marburg: Herder-Institut, 2000), 345-370.

123 Bozdağlığlu, Turkish Identity, 51. See also Ayşe Zarakol, After Defeat. How the East Learned to Live with the West (Cambridge: Cambridge University Press, 2011), 9. 